\title{
Highly lipophilic 3-epi-betulinic acid derivatives as potent and selective TGR5 agonists with improved cellular efficacy
}

\author{
Xiao-yin WANG, Shu-yong ZHANG, Jing LI, Hua-nan LIU, Xin XIE* , Fa-jun NAN* \\ State Key Laboratory of Drug Research, CAS Key Laboratory of Receptor Research, the National Center for Drug Screening, Shanghai \\ Institute of Materia Medica, Chinese Academy of Sciences, Shanghai 201203, China
}

\begin{abstract}
Aim: TGR5 is a G protein-coupled receptor that is expressed in intestinal L-cells and stimulates glucagon-like peptide 1 (GLP-1) secretion. TGR5 may represent a novel target for the treatment of metabolic disorder. Here, we sought to design and synthesize a series of TGR5 agonists derived from the natural product betulinic acid.

Methods: A series of betulinic acid derivatives were designed and synthesized. A cAMP assay was established using a HEK293 cell line expressing human TGR5. Luciferase reporter assay was established using HEK293 cells transfected with plasmids encoding human FXR and luciferase reporter. A human intestinal L-cell line $\mathrm{NCl}-\mathrm{H} 716$ was used to evaluate the effects of the betulinic acid derivatives on GLP-1 secretion in vitro.

Results: Biological data revealed that the $3-\alpha-\mathrm{OH}$ triterpenoids consistently show increased potency for TGR5 compared to their $3-\beta$ $\mathrm{OH}$ epimers. $3-\mathrm{OH}$ esterification increased the lipophilicity and TGR5 activity of 3- $\alpha$ betulinic derivatives and enhanced the activity differences between 3- $\alpha$ and 3- $\beta$ derivatives. The 3- $\alpha$-acyloxy betulinic acids also exhibited a significant dose-dependent GLP-1 secretion effect.

Conclusion: This study demonstrates that highly lipophilic 3-epi-betulinic acid derivatives can be potent and selective TGR5 agonists with improved cellular efficacy, and our research here provides a new strategy for the design and development of potent TGR5 agonists.
\end{abstract}

Keywords: TGR5; activator; betulinic acid derivatives; GLP-1; lipophilic; structure modifications

Acta Pharmacologica Sinica (2014) 35: 1463-1472; doi: 10.1038/aps.2014.97; published online Oct 62014

\section{Introduction}

G-protein coupled bile acid receptor 1 (GPBAR1, also known as TGR5) agonists have potential for the treatment of diabetes ${ }^{[1-3]}$. Bile acids (BAs), which are essential for dietary lipid absorption and cholesterol excretion, modulate the transcription of genes for enzymes and transport proteins through binding to the farnesoid $X$ receptor $(F X R)^{[4,5]}$. TGR5, which also functions as a bile acid receptor, has recently been identified as a mediator of several important metabolic processes in tissues including gallbladder, intestine, liver, brown adipose tissue and muscle ${ }^{[6-9]}$. Via TGR5 activation, BAs stimulate type 2 iodothyronine deiodinase activity, leading to increased mitochondrial function and thus energy expenditure ${ }^{[10]}$. BAs induce receptor internalization, activation of extracellular signal-regulated kinase, and intracellular cAMP production

\footnotetext{
* To whom correspondence should be addressed.

E-mail fjnan@simm.ac.cn (Fa-jun NAN); xxie@simm.ac.cn (Xin XIE)

Received 2014-04-21 Accepted 2014-05-17
}

in TGR5-expressing HEK293 and CHO cells ${ }^{[1,2]}$. In enteroendocrine cells, TGR5 activation has been shown to promote the secretion of glucagon-like peptide 1 (GLP-1) and peptide YY $(P Y Y)^{[1]}$. These findings indicate that TGR5 can transduce bile acid-induced signaling independently of nuclear receptormediated signaling. In animal models, treatment with TGR5 agonists induces GLP-1 secretion, which in turn induces insulin secretion, reduces blood glucose, increases basal energy expenditure and weight loss, and reduces blood lipid levels together with liver steatosis and fibrosis ${ }^{[7,11]}$. Therefore, TGR5 plays a critical role in vivo in the control of intestinal GLP-1 release and in the maintenance of glucose homeostasis. Pharmacological targeting of TGR5 may be a promising strategy for the treatment of diabetes and associated metabolic disorders.

Several TGR5 agonists have previously been reported, including synthetic small molecules as well as natural products and derivatives. Although some small molecule agonists such as compounds $\mathbf{1 a}^{[12]}$ and $\mathbf{1} \mathbf{b}^{[13]}$ (Figure 1) are usually more potent than bile acid derivatives, they generally suffer 


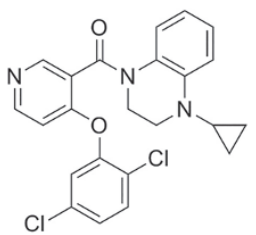

1a, $2 \mathrm{nmol} / \mathrm{L}$ (hTGR5)

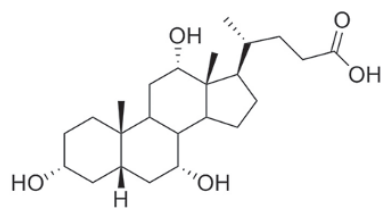

2a, Cholic acid, 13.6 $\mu \mathrm{mol} / \mathrm{L}$ (hTGR5)

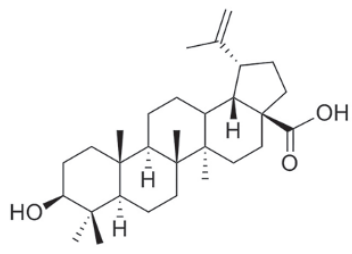

$3 \beta$, Betulinic acid, $2.25 \mu \mathrm{mol} / \mathrm{L}$ (hTGR5)

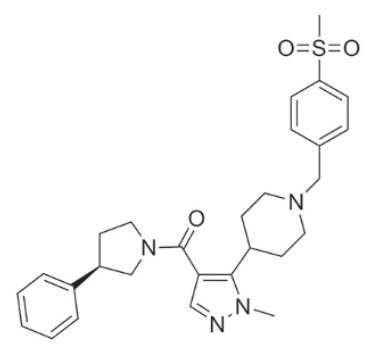

1b, $3 \mathrm{nmol} / \mathrm{L}$ (hTGR5)

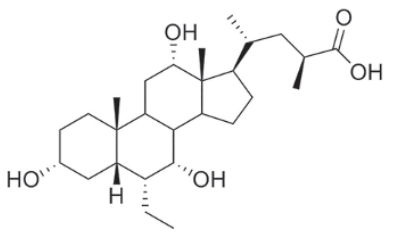

2b, INT777, $820 \mathrm{nmol} / \mathrm{L}(\mathrm{hTGR} 5)$

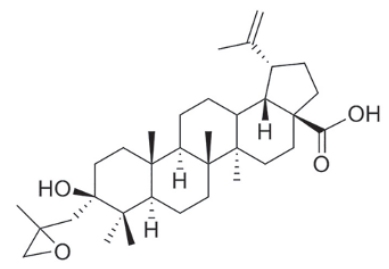

4, $47 \mathrm{nmol} / \mathrm{L}$ (hTGR5)

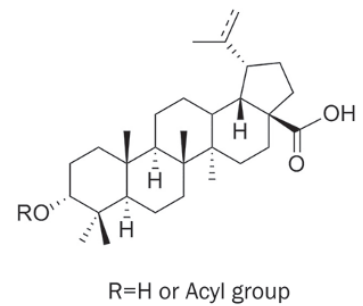

Figure 1. Known TGR5 agonists and their $E C_{50}$ values for hTGR5 and the design of 3- $\alpha$-betulinic acid derivatives as TGR5 agonists.

from undesired side effects. Most notable among these is an increase in gallbladder volume, as compound-induced TGR5 activation causes smooth muscle relaxation and promotes gallbladder filling $^{[14]}$. These disadvantages have limited further development of the synthetic small molecule agonists of TGR5. Natural products and their derivatives (eg, cholic acid, 2a), in contrast, seem to have some advantages, even though they have less potency than synthetic ones. 6-Ethyl-23(S)methyl cholic acid (S-EMCA, INT-777) $(\mathbf{2 b})^{[15,16]}$ is a particularly noteworthy derivative. It activates TGR5 with moderate potency $\left(\mathrm{EC}_{50}=0.82 \mu \mathrm{mol} / \mathrm{L}\right)$ and shows a range of beneficial metabolic effects on transgenic mice, including resistance to weight gain and hepatic steatosis, preservation of liver and pancreatic function, and the maintenance of glucose homeostasis and insulin sensitivity ${ }^{[7]}$. Based on these precedents, we chose to focus on natural product agonists of TGR5 as our starting point.

Betulinic acid (3及), a triterpenoid extracted from white birch leaves, has been reported to be a selective TGR5 agonist with moderate potency $\left(\mathrm{EC}_{50}=2.25 \mu \mathrm{mol} / \mathrm{L}\right)$ and antihyperglycemic effects $^{[17,18]}$. Structural modifications of the betulinic scaffold have previously been reported; the most potent compound of the series was an epoxy derivative (4) with an $\mathrm{EC}_{50}$ of $47 \mathrm{nmol} / \mathrm{L}^{[19]}$. In an effort to discover more potent TGR5 agonists, we compared the structure of betulinic acid (3 $\beta$ ) with compound 4 and noted the difference at the 3-position. Compound $\mathbf{4}$ and its analogues show a tolerance for an extra substituted group in the 3-a-face, and the introduction of certain small groups increases the affinity for TGR5 to varying degrees, whereas the same group in the 3 - $\beta$-face decreases TGR5 activity ${ }^{[20]}$. We hypothesized that a small hydrophobic group in the 3-a-face may be critical for potent TGR5 activity. Accordingly, we rationally designed a series of 3-a-OH betulinic acid analogues as novel TGR5 agonists. As outlined in Figure 1, we designed betulinic derivatives focusing on structural variation of the C-3 hydroxyl group and the C-20 alkene.

\section{Materials and methods} Chemistry

The synthesis of the first analogue, 3-a-OH-betulinic acid (3a) is outlined in Scheme 1. The carboxylic acid moiety of betulinic acid (3及) was first protected by heating to $60^{\circ} \mathrm{C}$ in DMF with benzyl chloride and potassium carbonate, yielding carboxylate 5 . The $3-\mathrm{OH}$ in 5 was then inverted by a two-step sequence of oxidation (Dess-Martin periodinane) ${ }^{[21]}$ and CBS reduction $\left(\mathrm{BH}_{3}-\mathrm{Me}_{2} \mathrm{~S}\right.$, (S)-CBS catalyst) ${ }^{[22]}$. 3-Epi benzyl-protected acid 7 was converted to analogue $3 a$ by hydrogenolysis
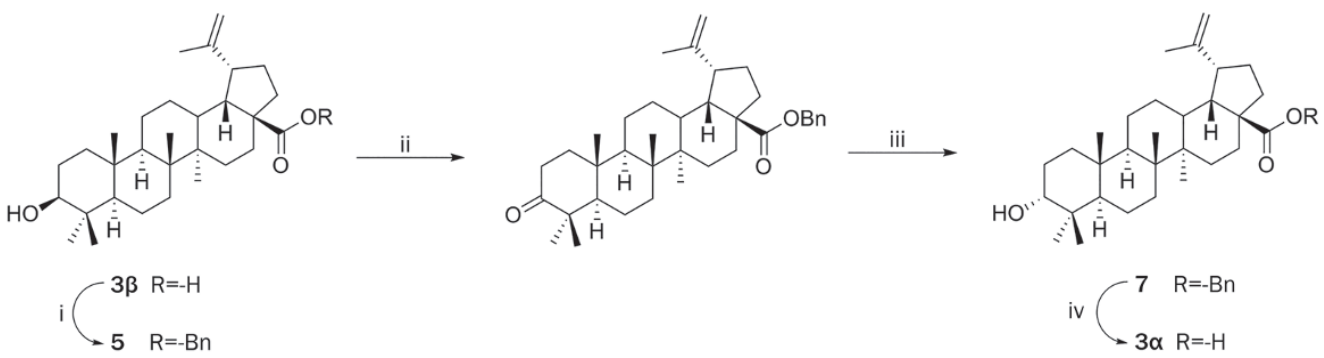

Scheme 1. Synthesis of $3 \alpha$. 
in the presence of palladium on a carbon catalyst $(\mathrm{Pd}-\mathrm{C})^{[23]}$.

Betulinic acid derivatives bearing modification of the C-3 alcohol and C-20 alkene were synthesized using strategies similar to that shown in Scheme 1 (Scheme 2 and 3). For each substitution pattern, pairs of 3- $\alpha$ and $3-\beta$ epimers were synthesized to assess the influence of C-3 configuration on TGR5 activity. As shown in Scheme 2, compound 7 was divergently reacted with acetic anhydride in DCM in the presence of triethylamine and DMAP and then deprotected to provide $\mathbf{8 a}$. Compounds $9 \mathbf{a}$ and 11a were obtained as shown in Scheme 3. Following reduction of the $\mathrm{C} 20$ alkene of betulinic acid to alkane $9 \beta$, the synthetic sequence from Scheme 1 was used to invert the $3-\mathrm{OH}$ and obtain compound $\mathbf{1 0}$. Compound $\mathbf{1 0}$ was deprotected to provide $9 \mathrm{a}$ and reacted similarly to Scheme 2 to

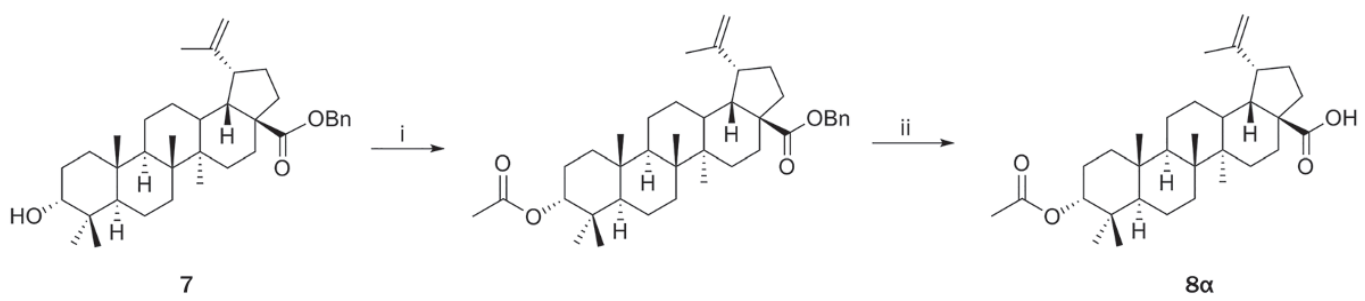

Scheme 2. Synthesis of $8 \alpha$.

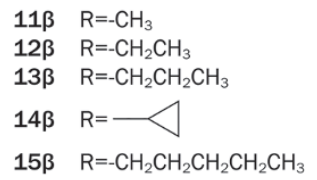

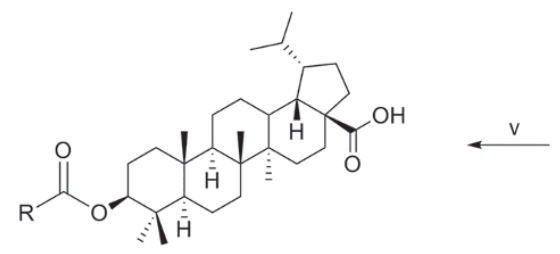

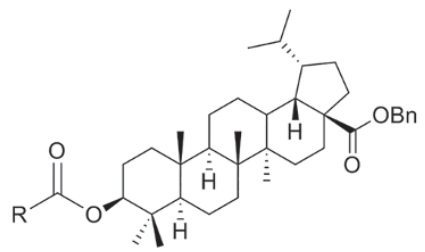

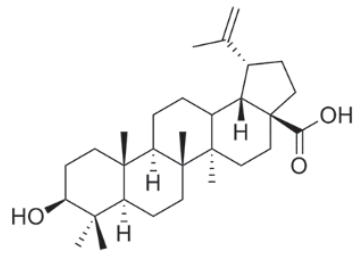

$3 \beta$

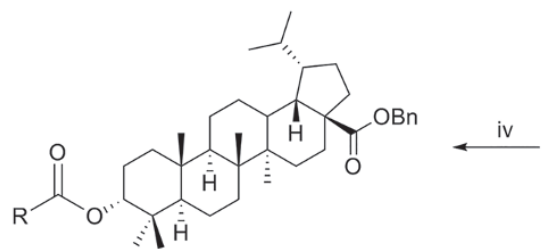<smiles>CC(C)(C)c1ccccc1</smiles>

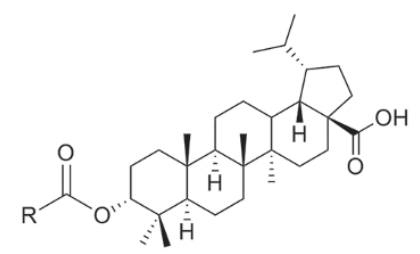

$11 \alpha \quad \mathrm{R}=-\mathrm{CH}_{3}$

$12 \alpha \quad \mathrm{R}=-\mathrm{CH}_{2} \mathrm{CH}_{3}$

$13 \alpha \quad \mathrm{R}=-\mathrm{CH}_{2} \mathrm{CH}_{2} \mathrm{CH}_{3}$

$14 \alpha \quad \mathrm{R}=\longrightarrow$

$15 \alpha \quad \mathrm{R}=-\mathrm{CH}_{2} \mathrm{CH}_{2} \mathrm{CH}_{2} \mathrm{CH}_{2} \mathrm{CH}_{3}$ 
provide 11a.

Reagents and conditions

Scheme 1

(i) $\mathrm{BnCl}, \mathrm{K}_{2} \mathrm{CO}_{3}, \mathrm{DMF}$; (ii) DMP, DCM; (iii) $\mathrm{BH}_{3}-\mathrm{Me}_{2} \mathrm{~S}$, (S)-CBS, THF; (iv) $\mathrm{H}_{2}$, Pd-C, MeOH.

\section{Scheme 2}

(i) $\left(\mathrm{CH}_{3} \mathrm{CO}\right)_{2} \mathrm{O}$, TEA, DMAP, DCM; (ii) $\mathrm{H}_{2}$, Pd-C, MeOH.

\section{Scheme 3}

(i) $\mathrm{H}_{2}, \mathrm{Pd}-\mathrm{C}, \mathrm{MeOH}$; (ii) $\mathrm{BnCl}, \mathrm{K}_{2} \mathrm{CO}_{3}, \mathrm{DMF}$; (iii) $\mathrm{DMP}, \mathrm{DCM}$; (iv) $(\mathrm{RCO})_{2} \mathrm{O}$, TEA, DMAP, DCM; (v) $\mathrm{H}_{2}, \mathrm{Pd}-\mathrm{C}, \mathrm{MeOH}$; (vi) $\mathrm{BH}_{3}-\mathrm{Me}_{2} \mathrm{~S}$, (S)-CBS, THF.

\section{Biological experiments} Reagents and materials

Lithocholic acid (LCA) and dimethyl sulfoxide (DMSO) were purchased from Sigma (St Louis, MO, USA). Human embryonic kidney (HEK) 293 cells, human NCI-H716 cells and human hepatocytes (HepG2 cell line) were obtained from the American Type Culture Collection (Manassas, Virginia, USA). Oligonucleotides were synthesized by Shanghai Sangon Co Ltd (Shanghai, China). Human TGR5 plasmid was purchased from the UMR cDNA Resource Center (Rolla, MO, USA).

\section{Plasmids}

A cDNA encoding human FXR-LBD was amplified by RT-PCR from human liver total mRNA according to methods described by ThermoScript ${ }^{\mathrm{TM}}$ RT-PCR System (Invitrogen, CA, USA). Briefly, the forward primer (5'-ACTGGATCCGTATGG GAATGTTGGCTGAATG-3') and the reverse primer (5'-ATC GGTACCTCACTGCACGTCCCAGATT-3') were used to amplify human FXR-LBD with the following regime: 30 cycles with denaturing at $94^{\circ} \mathrm{C}$ for $30 \mathrm{~s}$, annealing at $60^{\circ} \mathrm{C}$ for $1 \mathrm{~min}$, and extension at $72^{\circ} \mathrm{C}$ for $1 \mathrm{~min}$ followed by a final extension at $72{ }^{\circ} \mathrm{C}$ for $10 \mathrm{~min}$. The PCR product (FXR-LBD fragment) was then cloned into a pBind vector (Promega, Madison, WI, USA) and sequenced.

\section{Cell culture and transient transfections}

Human HepG2 and NCI-H716 cells were grown at $37^{\circ} \mathrm{C}$ in RPMI-1640 medium (GIBCO, GrandIsland, NY, USA), and HEK293 cells were maintained in Dulbecco's modified Eagle's medium (DMEM) supplemented with 10\% fetal bovine serum (FBS) and antibiotics (streptomycin/penicillin) in a humidified atmosphere containing $5 \% \mathrm{CO}_{2}$. For transient transfection, approximately $1 \times 10^{6}$ cells were mixed with 2 to $4 \mu \mathrm{g}$ plasmid in $200 \mu \mathrm{L}$ transfection buffer, and electroporation was carried out with a Scientz-2C electroporation apparatus (Scientz Biotech, Ningbo, China). For the cyclic-AMP (cAMP) assay, transient transfection was performed using human TGR5 plasmid. For luciferase reporter gene assays, transient co-transfection was then performed using pGL4.31[luc2P/GAL4UAS/Hygro] and the GAL4-FXR chimera expression plasmid pBINDFXR(LBD) by electroporation.
Cyclic-AMP (cAMP) assay

Cells were harvested with PBS and pelleted by centrifugation for $5 \mathrm{~min}$ at $1100 \mathrm{r} / \mathrm{min}$. Then, the cells were re-suspended in an appropriate volume of assay buffer (PBS containing 500 $\mu \mathrm{mol} / \mathrm{L}$ IBMX) to give a final cell count of $8 \times 10^{5}$ cells $/ \mathrm{mL}$. The cells were then plated into 384-well assay plates at 4000 cells/well in the volume of $5 \mu \mathrm{L}$. Another $5 \mu \mathrm{L}$ buffer containing compounds at various concentrations was added to the assay plates and incubated for $1 \mathrm{~h}$ at room temperature. Intracellular cAMP measurement was carried with a Cisbio HTRF Dynamic 2 cAMP kit (Cat No 62AM4PEJ) and an EnVision multiplate reader according to the manufacturer's instructions.

\section{Luciferase reporter gene assays}

Cells expressing pGL4.31[1uc2P/GAL4UAS/Hygro] Vector (Promega, Madison, WI, USA) and pBind-FXR were plated at a density of 10000 cells per well in a 96-well plate. After $24 \mathrm{~h}$ of culture, compounds at various concentrations were added. DMSO (1\%) was used as a negative control. GW4064 was used as positive control. Another $24 \mathrm{~h}$ later, luciferase activity was measured using the Steady-Glo ${ }^{\circledR}$ luciferase assay system (Promega, Madison, WI, USA) and an EnVision (PerkinElmer, Waltham, MA, USA) multiplate reader according to the manufacturer's instructions.

\section{GLP-1 secretion assay}

Two days before the experiments, $1.5 \times 10^{5}$ NCI-H716 cells were seeded in 384-well culture plates coated with Matrigel. On the day of the experiment, cells were incubated for $2 \mathrm{~h}$ at $37^{\circ} \mathrm{C}$ with the different effectors or with DMSO. Supernatants were collected and frozen at $-80^{\circ} \mathrm{C}$ for subsequent analysis. Biologically active GLP-1 (7-36) was measured as described by the Active GLP-1 assay kit (HTRF, 62GLPPEK).

\section{Results and discussion}

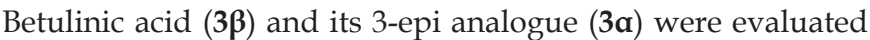
for their ability to activate TGR5 and FXR using a cyclic-AMP (cAMP) assay and a reporter assay, respectively (Table 1); INT-777 was used as a reference control. 3a showed slightly increased potency for TGR5 compared to $\mathbf{3} \boldsymbol{\beta}$, and both compounds displayed good efficacy and excellent selectivity for TGR5 over FXR. These initial findings encouraged us to synthesize and evaluate further 3- $\alpha$-triterpenoid analogues.

$8 \alpha / \beta, 9 \alpha / \beta$, and $11 \alpha / \beta$ were again evaluated for their ability to activate TGR5 and FXR (Table 2). The 3-a-OH derivatives consistently showed increased potency for TGR5 compared to their 3- $\beta-\mathrm{OH}$ epimers. All the analogues lacked FXR activity. Interestingly, acetylation at the 3 position markedly increased their potency as TGR5 agonists while preserving their selectivity for TGR5 over FXR. Note the difference between the hydroxyl analogues $\mathbf{9 \alpha}$ and $\mathbf{9} \boldsymbol{\beta}$, which showed similar activity,

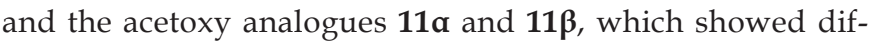
ferent total activity. In particular, 11a showed an $\mathrm{EC}_{50}$ of 237 $\mathrm{nmol} / \mathrm{L}$, which is more potent than INT-777.

As shown in Table 3, esterification at C-3 increased potency for TGR5 compared to betulinic acid while retaining selec- 
Table 1. TGR5 and FXR activities of triterpenoids. Data are presented as mean $\pm \operatorname{SEM}(n=3)$.

\begin{tabular}{lccc}
\hline Name & \multicolumn{2}{c}{ TGR5 } & $\begin{array}{c}\text { FXR } \\
\mathrm{EC}_{50} / \mathrm{nmol}^{-1}\end{array}$ \\
\hline GW4064 & - & - & $48.82 \pm 0.4$ \\
INT-777 & $395.1 \pm 125.6$ & $100.0 \pm 0.7$ & $\mathrm{NR}$ \\
$3 \alpha$ & $1914 \pm 473.3$ & $95.27 \pm 0.7$ & $\mathrm{NR}$ \\
$3 \beta$ & $3214 \pm 385.6$ & $83.15 \pm 4.0$ & $\mathrm{NR}$ \\
\hline
\end{tabular}

$\mathrm{EC}_{50}$ and efficacy generated from human TGR5-based cAMP assay or human FXR-based reporter assay. NR=No response at concentrations up to $100 \mu \mathrm{mol} / \mathrm{L}$.

Table 2. TGR5 and FXR activities of triterpenoids. Data are presented as mean $\pm \operatorname{SEM}(n=3)$.

\begin{tabular}{llcc}
\hline \multirow{2}{*}{ Name } & \multicolumn{2}{c}{ TGR5 } & $\begin{array}{c}\text { FXR } \\
E_{50} / \mathrm{nmol}^{-L^{-1}}\end{array}$ \\
\hline GW4064 & - & - & $48.82 \pm 0.4$ \\
INT-777 & $469.0 \pm 94.3$ & $100.0 \pm 0.7$ & $\mathrm{NR}$ \\
$8 \alpha$ & $577.4 \pm 86.3$ & $89.77 \pm 1.2$ & $\mathrm{NR}$ \\
$\mathbf{8} \beta$ & $7082 \pm 453.6$ & $87.67 \pm 1.3$ & $\mathrm{NR}$ \\
$9 \alpha$ & $3190 \pm 443.8$ & $90.19 \pm 1.3$ & $\mathrm{NR}$ \\
$9 \beta$ & $3979 \pm 994.1$ & $93.04 \pm 0.8$ & $\mathrm{NR}$ \\
$11 \alpha$ & $237.8 \pm 73.6$ & $91.63 \pm 0.4$ & $\mathrm{NR}$ \\
$11 \beta$ & $1867 \pm 432.9$ & $84.03 \pm 1.5$ & $\mathrm{NR}$ \\
\hline
\end{tabular}

$\mathrm{EC}_{50}$ and efficacy generated from human TGR5-based cAMP assay or human FXR-based reporter assay. NR=No response at concentrations up to $100 \mu \mathrm{mol} / \mathrm{L}$.

tivity for TGR5 over FXR. The results from these $\boldsymbol{\alpha} / \boldsymbol{\beta}$ pairs compared to $11 \mathrm{\alpha} / \boldsymbol{\beta}$ indicate a lipophilic effect on the difference in activity between the two isomeric 3-ester derivatives. Whereas compounds $\mathbf{1 2 \alpha - 1 4 a}$ have $\mathrm{EC}_{50} \mathrm{~s}$ of several hundred nanomolar, their $3-\beta$-epimers are inactive at concentrations up to $100 \mu \mathrm{mol} / \mathrm{L}$. Notice compound 15a, which showed an $\mathrm{EC}_{50}$ of $477.7 \mathrm{nmol} / \mathrm{L}$ but reduced efficacy (38\%) compared to 12a, 13a, and 14a. That indicates a tolerance for small groups in the 3 position, whereas a large group will cause a loss of activity. Taken together, these data reveal that a free hydroxyl at the 3-a-face, although important, is not indispensable for TGR5 activity, and small lipophilic groups at the 3-a-face may contribute further hydrophobic attraction and increase the potency. This finding improves our knowledge of TGR5 and is in partial accordance with the structure activity relationship (SAR) described by Saladin's team ${ }^{[17,18]}$.

In light of the excellent in vitro activity of the 3-a-betulinic derivatives and their good selectivity for TGR5 over FXR, compounds $12 \alpha / \beta, 13 \alpha / \beta$, and $14 \alpha / \beta$ were tested in an in vitro GLP-1 secretion assay (Figure 2). We hypothesized their activity would be sufficient to activate TGR5 in the intestine, increasing GLP-1 secretion and lowering blood glucose levels. Compounds 12a, 13a, and 14a, which have 3-a-acyloxy groups, significantly induced the release of GLP-1, whereas their 3- $\beta$-acyloxy counterparts showed no activity at the same concentration. These results correlate well with the cell-based agonistic activities shown in Table 3.

As mentioned before, TGR5 is distributed in many tissues such as gallbladder, intestine, liver, brown adipose tissue and muscle ${ }^{[6-9]}$. Activation of TGR5 in the intestines stimulates GLP-1 secretion and lowers blood glucose levels. Activation of TGR5 in other tissues, however, can lead to undesired side effects. In the gallbladder, TGR5 activation causes smooth muscle relaxation and promotes gallbladder filling ${ }^{[24,25]}$. Gallbladder toxicity has been reported for many TGR5 agonists due to high exposure to bile. Toxicity to the cardiovascular system caused by hERG inhibition of TGR5 agonists has also been reported ${ }^{[26,27]}$. Accordingly, an ideal therapy should stimulate GLP-1 secretion in the intestine only and should have low systemic exposure to prevent the activation of TGR5 in other tissues. In fact, two isoxazolecarboxamide TGR5 agonists have demonstrated that systemic exposure is not neces-

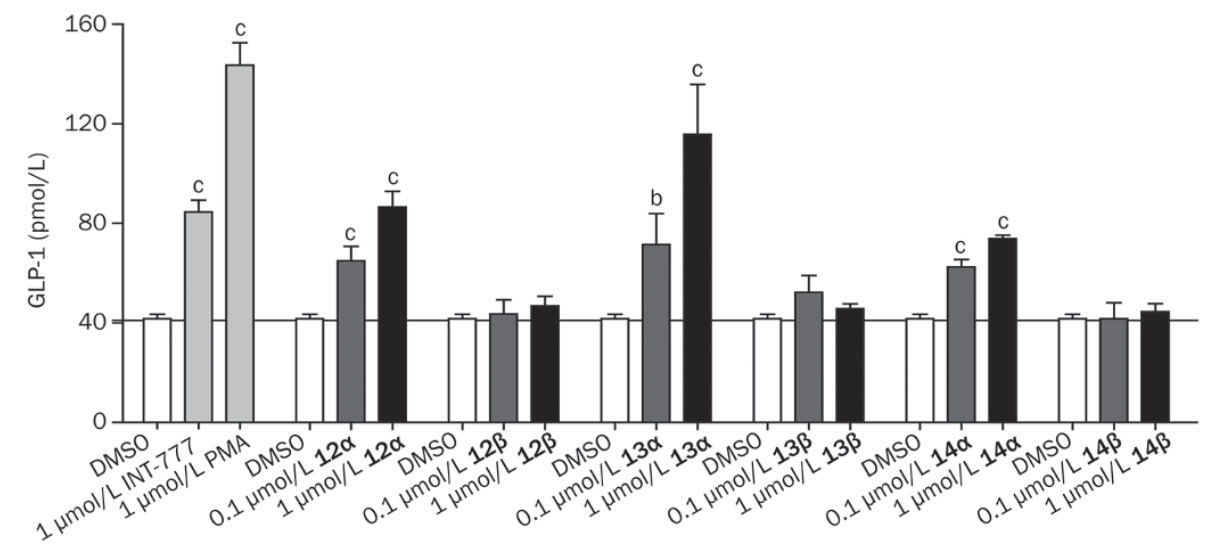

Figure 2. GLP-1 release by NCl-H716 cells. GLP-1 release into $\mathrm{NCl}-\mathrm{H} 716$ cell culture supernatant was investigated after an incubation period of $2 \mathrm{~h}$ at $37^{\circ} \mathrm{C}$. The concentration of GLP-1 was determined by Active GLP-1 assay kit. INT-777 ( $\left.1 \mu \mathrm{mol} / \mathrm{L}\right)$ and phorbol-12-myristate-13-acetate (PMA, $\left.1 \mu \mathrm{mol} / \mathrm{L}\right)$ were used as positive controls. Data are presented as the mean \pm SEM $(n=3)$. ${ }^{b} P<0.05,{ }^{c} P<0.01$ vs DMSO control. 
Table 3. TGR5 and FXR activities of triterpenoids. Data are presented as mean $\pm \operatorname{SEM}(n=3)$.

\begin{tabular}{lccc}
\hline \multirow{2}{*}{ Name } & \multicolumn{2}{c}{ TGR5 } & $\begin{array}{c}\text { FXR } \\
\mathrm{EC}_{50} / \mathrm{nmol} \cdot \mathrm{L}^{-1}\end{array}$ \\
& $\mathrm{EC}_{50} /{\mathrm{nmol} \cdot \mathrm{L}^{-1}}$ & Efficacy & $48.82 \pm 0.4$ \\
GW4064 & - & - & $\mathrm{NR}$ \\
INT-777 & $469.0 \pm 94.3$ & $100.0 \pm 0.7$ & $\mathrm{NR}$ \\
$12 \alpha$ & $313.4 \pm 102.9$ & $89.49 \pm 0.7$ & $\mathrm{NR}$ \\
$12 \beta$ & $\mathrm{NR}$ & 0 & $\mathrm{NR}$ \\
$13 \alpha$ & $455.7 \pm 148.6$ & $88.50 \pm 0.8$ & $\mathrm{NR}$ \\
$13 \beta$ & $\mathrm{NR}$ & 0 & $\mathrm{NR}$ \\
$14 \alpha$ & $303.8 \pm 85.9$ & $91.39 \pm 0.6$ & $\mathrm{NR}$ \\
$14 \beta$ & $\mathrm{NR}$ & 0 & $\mathrm{NR}$ \\
$15 \alpha$ & $477.7 \pm 84.9$ & $32.89 \pm 2.9$ & $\mathrm{NR}$ \\
$15 \beta$ & $\mathrm{NR}$ & 0 & \\
\hline
\end{tabular}

$\mathrm{EC}_{50}$ and efficacy generated from human TGR5-based cAMP assay or human FXR-based reporter assay. NR=No response at concentrations up to $100 \mu \mathrm{mol} / \mathrm{L}$.

sary to achieve the desired effect of stimulating GLP-1 secretion in $v i v o^{[24]}$. Previous studies have shown that triterpenoids often have poor solubility and poor absorption in the gastrointestinal tract, leading to low plasma exposure ${ }^{[28,29]}$. This may reduce the activation of TGR5 in gallbladder and other tissues caused by high plasma exposure, thereby reducing the side effects. As shown by the clogP values in Table 4 (calculated by ChemDraw), the acyloxy-betulinic derivatives generally have higher lipophilicity than betulinic acid and compound 4, which may further lower their bioavailability and systemic exposure. Researchers at Lilly have found that drugs for GPCRs (lipid GPCRs) have higher clogP values and properties opposite to Lipinski's "rule of five." Drugs with high $M_{\mathrm{W}}$ and clogP seem to have more affinity for GPCRs and may cause fewer side effects ${ }^{[30]}$. Therefore, the present acyloxy betulinic derivatives may activate intestinal TGR5 while minimizing side effects due to systemic exposure.

We next evaluated the preliminary pharmacokinetic profile of compound 12a with the aim of gaining insights into the efficiency of its oral absorption and intestinal stability. After oral gavage administration of $12 \alpha(10 \mathrm{mg} / \mathrm{kg})$ to rats, the concentration of $12 \alpha$ in plasma and in urine was below $5 \mathrm{ng} / \mathrm{mL}$ and

Table 4. clogP of derivatives.

\begin{tabular}{llll}
\hline Name & clogP & Name & clogP \\
\hline INT-777 & 3.003 & $\mathbf{4}$ & 5.496 \\
$3 \alpha$ & 4.926 & $3 \beta$ & 4.926 \\
$8 \alpha$ & 5.834 & $\mathbf{8 \beta}$ & 5.834 \\
$9 \alpha$ & 5.410 & $9 \beta$ & 5.410 \\
$11 \alpha$ & 6.318 & $11 \beta$ & 6.318 \\
$12 \alpha$ & 6.847 & $12 \beta$ & 6.847 \\
$13 \alpha$ & 7.376 & $13 \beta$ & 7.376 \\
$14 \alpha$ & 6.902 & $14 \beta$ & 6.902 \\
\hline
\end{tabular}

clogP values are calculated by ChemDraw 2010.
$1 \mathrm{ng} / \mathrm{mL}$, respectively, and an average of $85 \%$ of compound $12 \alpha$ can be recovered from stool. These results are in line with our expectations, that our compounds have low plasma exposure and are mostly located in the intestine.

\section{Conclusion}

In conclusion, we have described the synthesis and biological evaluation of a series of 3- $\alpha$ and $3-\beta$-triterpenoid derivatives as TGR5 agonists. The biological data reveal that the $3-\alpha-O H$ triterpenoids consistently show increased potency for TGR5 compared to their $3-\beta-\mathrm{OH}$ epimers. Esterification of $3-\mathrm{OH}$ produces compounds with increased potency for TGR5 while retaining selectivity for TGR5 over FXR. The difference in TGR5 activity between the two isomeric 3-ester derivatives was also higher. An in vitro GLP-1 secretion study indicated that compound 13a dose-dependently induces the release of GLP-1. Further studies and additional pharmacokinetic evaluation are now underway, and the results will be reported in due course.

\section{Experimental section \\ General methods}

NMR spectra were obtained with a Varian Mercury-VX300 spectrometer, and the chemical shifts are reported in parts per million (ppm). The abbreviations used are as follows: s, singlet; bs, broad singlet; d, doublet; dd, double doublet; m, multiplet. Flash chromatography was performed using silica gel zcx-11 (0.050-0.075 mm). TLC was carried out on pre-coated TLC plates with silica gel HSGF 254. Spots were visualized by staining and warming with phosphomolybdate reagent (5\% solution in EtOH). All reactions were carried out under a nitrogen atmosphere. MS data were obtained with a MICROMASS Q-Tof Ultima ${ }^{\mathrm{TM}}$ spectrometer.

\section{Benzyl 3(ß)-hydroxylup-20(29)-en-28-oate (5)}

$3 \beta(4 \mathrm{~g}, 8.76 \mathrm{mmol})$ was dissolved in DMF (50 mL) and $\mathrm{K}_{2} \mathrm{CO}_{3}$ $(2.4 \mathrm{~g}, 17.37 \mathrm{mmol})$ was added to the reaction mixture followed by benzyl chloride $(1.2 \mathrm{~mL}, 10.52 \mathrm{mmol})$. The reaction mixture was stirred at $50^{\circ} \mathrm{C}$ overnight. The mixture was cooled to room temperature, slowly diluted with $\mathrm{H}_{2} \mathrm{O}(100 \mathrm{~mL})$ and extracted with EtOAc $(2 \times 100 \mathrm{~mL})$. The combined organic layers were washed with $\mathrm{H}_{2} \mathrm{O}(2 \times 150 \mathrm{~mL})$, brine $(150 \mathrm{~mL})$, dried over $\mathrm{Na}_{2} \mathrm{SO}_{4}$ and evaporated under reduced pressure to obtain the desired compound 5 (4.62 g, $8.46 \mathrm{mmol}, 97 \%)$ as a white solid, which was used for the next step without further purification. ${ }^{1} \mathrm{H} \mathrm{NMR}\left(300 \mathrm{MHz}, \mathrm{CDCl}_{3}\right) \delta 7.34(\mathrm{~m}, 5 \mathrm{H}), 5.09$ (d, 1H, J=11.7 Hz), 5.17 (d, 1H, J=11.7 Hz), 4.75 (s, 1H), 4.62 (s, $1 \mathrm{H}), 3.21-3.15(\mathrm{~m}, 1 \mathrm{H}), 2.92-2.80(\mathrm{~m}, 1 \mathrm{H}), 2.10-1.90(\mathrm{~m}, 2 \mathrm{H})$, 1.87-1.69 (m, 2H), $1.64(\mathrm{~s}, 3 \mathrm{H}), 1.64-0.96(\mathrm{~m}$, other aliphatic ring protons), $1.04(\mathrm{~s}, 3 \mathrm{H}), 1.00(\mathrm{~s}, 3 \mathrm{H}), 0.94(\mathrm{~s}, 3 \mathrm{H}), 0.91(\mathrm{~s}, 3 \mathrm{H})$, $0.87(\mathrm{~s}, 3 \mathrm{H}), 0.84(\mathrm{~s}, 3 \mathrm{H})$.

\section{Benzyl 3-carbonylup-20(29)-en-28-oate (6)}

To a solution of compound 5 (4.62 g, $8.46 \mathrm{mmol})$ in DCM (100 $\mathrm{mL})$ Dess-Martin Periodinane $(4.3 \mathrm{~g}, 10.15 \mathrm{mmol})$ was added slowly at $0^{\circ} \mathrm{C}$. The mixture was stirred at room temperature 
overnight. The suspension was filtered and the filtrate was concentrated and purified by flash chromatography using 5\% EtOAc in petroleum ether to yield $4.39 \mathrm{~g}(8.06 \mathrm{mmol}, 95 \%)$ of 6 as a white pure solid. ${ }^{1} \mathrm{H}$ NMR $\left(300 \mathrm{MHz}, \mathrm{CDCl}_{3}\right) \delta 7.34(\mathrm{~m}$, $5 \mathrm{H}), 5.09$ (d, $1 \mathrm{H}, \mathrm{J}=11.7 \mathrm{~Hz}), 5.17$ (d, $1 \mathrm{H}, \mathrm{J}=11.7 \mathrm{~Hz}), 4.75$ (s, $1 \mathrm{H}), 4.62(\mathrm{~s}, 1 \mathrm{H}), 2.92-2.80(\mathrm{~m}, 1 \mathrm{H}), 2.49-2.39(\mathrm{~m}, 2 \mathrm{H}), 2.10-$ $2.04(\mathrm{~m}, 2 \mathrm{H}), 1.92-1.80(\mathrm{~m}, 2 \mathrm{H}), 1.78-1.68(\mathrm{~m}, 2 \mathrm{H}), 1.65(\mathrm{~s}, 3 \mathrm{H})$, 1.50-1.16 (m, other aliphatic ring protons), $1.04(\mathrm{~s}, 3 \mathrm{H}), 1.00$ (s, $3 \mathrm{H}), 0.94(\mathrm{~s}, 3 \mathrm{H}), 0.91(\mathrm{~s}, 3 \mathrm{H}), 0.87(\mathrm{~s}, 3 \mathrm{H}), 0.84(\mathrm{~s}, 3 \mathrm{H})$.

\section{Benzyl 3( $\alpha$ )-hydroxylup-20(29)-en-28-oate (7)}

To a solution of compound $6(1.58 \mathrm{~g}, 2.90 \mathrm{mmol})$ and $(S)-(-)-$ 2-methyl-CBS-oxazaborolidine $(80 \mathrm{mg}, 0.29 \mathrm{mmol})$ in dry THF $(50 \mathrm{~mL})$ a solution of $\mathrm{BH}_{3}-\mathrm{Me}_{2} \mathrm{~S}(0.32 \mathrm{~mL}, 10 \mathrm{~mol} / \mathrm{L}$ in THF) was added dropwise at room temperature under nitrogen atmosphere. After $10 \mathrm{~min}, \mathrm{MeOH}$ was added to quench the reaction, and the reaction mixture was concentrated and purified by flash chromatography using 5\% EtOAc in petroleum ether to yield $790 \mathrm{mg}(1.45 \mathrm{mmol}, 50 \%)$ of 7 as a white pure solid. ${ }^{1} \mathrm{H}$ NMR (300 MHz, $\left.\mathrm{CDCl}_{3}\right) \delta 7.34(\mathrm{~m}, 5 \mathrm{H}), 5.09(\mathrm{~d}, 1 \mathrm{H}$, $\mathrm{J}=11.7 \mathrm{~Hz}), 5.17$ (d, 1H, J=11.7 Hz), 4.73 (s, 1H), 4.60 (s, 1H), $3.39(\mathrm{~s}, 1 \mathrm{H}), 3.02-2.96(\mathrm{~m}, 1 \mathrm{H}), 2.28-2.16(\mathrm{~m}, 2 \mathrm{H}), 1.98-1.95(\mathrm{~m}$, $2 \mathrm{H}), 1.68(\mathrm{~s}, 3 \mathrm{H}), 1.64-0.96(\mathrm{~m}$, other aliphatic ring protons), $1.04(\mathrm{~s}, 3 \mathrm{H}), 1.00(\mathrm{~s}, 3 \mathrm{H}), 0.94(\mathrm{~s}, 3 \mathrm{H}), 0.91(\mathrm{~s}, 3 \mathrm{H}), 0.87(\mathrm{~s}, 3 \mathrm{H})$, $0.84(\mathrm{~s}, 3 \mathrm{H})$.

\section{3-Epi-betulinic acid (3 $\mathbf{\alpha})$}

To a stirred solution of $7(100 \mathrm{mg}, 0.18 \mathrm{mmol})$ in a mixture of EA/MeOH $(1 / 4 \mathrm{~mL}), \mathrm{Pd} / \mathrm{C}(10 \mathrm{mg})$ was added at room temperature under nitrogen atmosphere. The nitrogen atmosphere was replaced by an $\mathrm{H}_{2}$ atmosphere. The reaction mixture was stirred for $1 \mathrm{~h}$ at room temperature, then $\mathrm{N}_{2}$ was replaced, and it was filtered through Celite and washed with DCM. The residue was purified by flash chromatography using 10\% EtOAc in petroleum ether to yield $78 \mathrm{mg}(0.17$ mmol, $94 \%)$ of $3 \alpha$ as a white pure solid. ${ }^{1} \mathrm{H}$ NMR $(300 \mathrm{MHz}$, $\left.\mathrm{CDCl}_{3}\right) \delta 4.73(\mathrm{~s}, 1 \mathrm{H}), 4.60(\mathrm{~s}, 1 \mathrm{H}), 3.39(\mathrm{~s}, 1 \mathrm{H}), 3.02-2.96(\mathrm{~m}$, $1 \mathrm{H}), 2.28-2.16(\mathrm{~m}, 2 \mathrm{H}), 1.98-1.95(\mathrm{~m}, 2 \mathrm{H}), 1.68(\mathrm{~s}, 3 \mathrm{H}), 1.64-$ $0.96(\mathrm{~m}$, other aliphatic ring protons $), 1.04(\mathrm{~s}, 3 \mathrm{H}), 1.00(\mathrm{~s}, 3 \mathrm{H})$, $0.94(\mathrm{~s}, 3 \mathrm{H}), 0.91$ (s, 3H), $0.87(\mathrm{~s}, 3 \mathrm{H}), 0.84(\mathrm{~s}, 3 \mathrm{H}) .{ }^{13} \mathrm{C}$ NMR $\left(75 \mathrm{MHz}, \mathrm{CD}_{3} \mathrm{OD}+\mathrm{CDCl}_{3}\right) \delta 179.34,150.89,109.51,76.14,56.43$, $50.45,49.41,44.40,42.66,41.02,38.46,38.32$, 37.64, 37.40, 34.45, $33.44,32.44,30.75,29.89,28.26,27.17,25.73,22.97,22.20,20.95$, $19.30,18.37,16.01,14.67,14.63$. HRMS, calcd. $\left(\mathrm{M}+\mathrm{H}^{+}\right) \mathrm{m} / \mathrm{e}$ 457.3682, observed 457.3501.

\section{Benzyl 3( $\alpha$ )-acetoxylup-20(29)-en-28-oate}

To a stirred solution of $7(107 \mathrm{mg}, 0.20 \mathrm{mmol})$, TEA $(82 \mu \mathrm{L}$, $0.60 \mathrm{mmol})$ and DMAP (10 mg, $0.08 \mathrm{mmol})$ in dry DCM (10 $\mathrm{mL})$ acetic anhydride $(57 \mu \mathrm{L}, 0.60 \mathrm{mmol})$ was added dropwise at $0{ }^{\circ} \mathrm{C}$. Then, the reaction mixture was allowed to stir at room temperature overnight. The mixture was concentrated and diluted with $\mathrm{H}_{2} \mathrm{O}(20 \mathrm{~mL})$ and extracted with EtOAc $(2 \times 10$ $\mathrm{mL}$ ). The combined organic layers were washed with $\mathrm{H}_{2} \mathrm{O}$ $(2 \times 20 \mathrm{~mL})$, brine $(20 \mathrm{~mL})$, and dried over $\mathrm{Na}_{2} \mathrm{SO}_{4}$. The mixture was cooled to room temperature, slowly diluted with $\mathrm{H}_{2} \mathrm{O}$
$(100 \mathrm{~mL})$ and extracted with EtOAc $(2 \times 100 \mathrm{~mL})$. The combined organic layers were washed with $\mathrm{H}_{2} \mathrm{O}(2 \times 150 \mathrm{~mL})$, brine $(150 \mathrm{~mL})$, dried over $\mathrm{Na}_{2} \mathrm{SO}_{4}$ and concentrated. The residue was purified by flash chromatography using 5\% EtOAc in petroleum ether to yield $77 \mathrm{mg}(0.13 \mathrm{mmol}, 65 \%)$ of product as a white pure solid. ${ }^{1} \mathrm{H}$ NMR $\left(300 \mathrm{MHz} \mathrm{CDCl}_{3}\right) \delta 7.34(\mathrm{~m}, 5 \mathrm{H})$, 5.09 (d, 1H, J=11.7 Hz), 5.17 (d, 1H, J=11.7 Hz), 4.62 (s, 1H), 2.84-2.20 (m, 4H), $2.08(\mathrm{~s}, 3 \mathrm{H}), 1.98-1.15(\mathrm{~m}$, other aliphatic ring protons), $1.01(\mathrm{~s}, 3 \mathrm{H}), 0.94(\mathrm{~s}, 3 \mathrm{H}), 0.92(\mathrm{~s}, 3 \mathrm{H}), 0.85(\mathrm{~s}, 3 \mathrm{H})$, $0.83(\mathrm{~s}, 3 \mathrm{H}), 0.76(\mathrm{~s}, 3 \mathrm{H}), 0.74(\mathrm{~s}, 3 \mathrm{H})$.

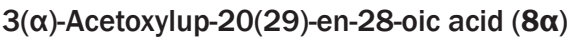

Prepared by deprotection of benzyl 3(a)-acetoxylup-20(29)-en28-oate as previously described for 3a. Yield: 94\%. ${ }^{1} \mathrm{H}$ NMR $\left(300 \mathrm{MHz}, \mathrm{CDCl}_{3}\right) \delta 4.73(\mathrm{~s}, 1 \mathrm{H}), 4.60(\mathrm{~s}, 1 \mathrm{H}+1 \mathrm{H}), 3.04-2.96(\mathrm{~m}$, $1 \mathrm{H}), 2.29-2.12(\mathrm{~m}, 2 \mathrm{H}), 2.07$ (s, 3H), 1.98-1.82 (m, 2H), 1.68 (s, $3 \mathrm{H}), 1.64-0.96(\mathrm{~m}$, other aliphatic ring protons $), 1.04(\mathrm{~s}, 3 \mathrm{H})$, $1.00(\mathrm{~s}, 3 \mathrm{H}), 0.94(\mathrm{~s}, 3 \mathrm{H}), 0.91(\mathrm{~s}, 3 \mathrm{H}), 0.87(\mathrm{~s}, 3 \mathrm{H}), 0.84(\mathrm{~s}, 3 \mathrm{H})$. ${ }^{13} \mathrm{C} \mathrm{NMR}\left(75 \mathrm{MHz} \mathrm{CDCl}_{3}\right) \delta 171.15,150.61,109.90,78.62,56.66$, $50.44,49.48,47.14,44.40,42.72,41.07,38.62,37.42,36.88,34.29$, $34.09,32.41,30.81,29.93,28.05,25.68,23.23,23.10,21.91,21.63$, $20.89,19.62,18.30,16.26,16.12,15.15,14.89$. HRMS, calcd. $\left(\mathrm{M}+\mathrm{K}^{+}\right) \mathrm{m} / \mathrm{e}$ 537.3346, observed 537.3909.

\section{3(ß)-Acetoxylup-20(29)-en-28-oic acid (8ß)}

Prepared as previously described for 8 a. Yield: $36 \%$ (three steps). ${ }^{1} \mathrm{H}$ NMR (300 MHz, $\left.\mathrm{CDCl}_{3}\right) \delta 4.73(\mathrm{~s}, 1 \mathrm{H}), 4.47(\mathrm{t}, 1 \mathrm{H}$, $\mathrm{J}=7.5 \mathrm{~Hz}), 3.04-2.96(\mathrm{~m}, 1 \mathrm{H}), 2.29-2.12(\mathrm{~m}, 2 \mathrm{H}), 2.04(\mathrm{~s}, 3 \mathrm{H})$, 1.98-1.90 (m, 2H), $1.69(\mathrm{~s}, 3 \mathrm{H}), 1.64-0.96(\mathrm{~m}$, other aliphatic ring protons), $0.97(\mathrm{~s}, 3 \mathrm{H}), 0.92(\mathrm{~s}, 3 \mathrm{H}), 0.84(\mathrm{~s}, 3 \mathrm{H}), 0.82(\mathrm{~s}, 3 \mathrm{H})$, 0.77 (s, 3H), $0.74(\mathrm{~s}, 3 \mathrm{H}) .{ }^{13} \mathrm{C}$ NMR $\left(75 \mathrm{MHz}, \mathrm{CDCl}_{3}\right) \delta 171.36$, 150.60, 109.97, 81.20, 55.61, 50.58, 49.47, 47.17, 42.46, 40.89, $38.59,38.01,37.63,37.31,34.45,32.39,31.85,30.78,29.91,28.17$, 25.64, 21.57, 21.06, 20.90, 19.57, 18.37, 16.69, 16.40, 16.26, 15.15, 14.88, 14.80. HRMS, calcd. $\left(\mathrm{M}+\mathrm{K}^{+}\right) \mathrm{m} / \mathrm{e} 537.3346$, observed 537.3892 .

\section{3( $\beta$ )-Hydroxylupan-28-oic acid (9ß)}

To a stirred solution of $3 \beta(1.2 \mathrm{~g}, 2.63 \mathrm{mmol})$ in a mixture of $\mathrm{EA} / \mathrm{MeOH}(10 / 40 \mathrm{~mL}), \mathrm{Pd} / \mathrm{C}(150 \mathrm{mg})$ was added at room temperature under nitrogen atmosphere. The nitrogen atmosphere was replaced by an $\mathrm{H}_{2}$ atmosphere. The reaction mixture was stirred for $2 \mathrm{~d}$ at room temperature; then, the $\mathrm{N}_{2}$ was replaced, and it was filtered through Celite and washed with DCM. The residue was purified by flash chromatography using 10\% EtOAc in petroleum ether to yield $1.04 \mathrm{~g}$ (2.27 mmol, $86 \%)$ of $\mathbf{9 \beta}$ as a white pure solid. ${ }^{1} \mathrm{H} \mathrm{NMR}(300 \mathrm{MHz}$, $\left.\mathrm{CDCl}_{3}\right) \delta 3.13(\mathrm{t}, 1 \mathrm{H}, \mathrm{J}=9.0,6.9 \mathrm{~Hz}), 2.28-2.16(\mathrm{~m}, 2 \mathrm{H}), 1.98-1.78$ $(\mathrm{m}, 4 \mathrm{H}), 1.64-0.96(\mathrm{~m}$, other aliphatic ring protons), $0.96(\mathrm{~s}$, $3 \mathrm{H}), 0.93$ (s, 3H), $0.92(\mathrm{~s}, 3 \mathrm{H}), 0.90(\mathrm{~s}, 3 \mathrm{H}), 0.89$ (s, 3H), 0.87 (s, $3 \mathrm{H}), 0.78(\mathrm{~s}, 3 \mathrm{H}) .{ }^{13} \mathrm{C} \mathrm{NMR}\left(75 \mathrm{MHz}, \mathrm{CDCl}_{3}\right) \delta 179.42,78.80$, 56.72, 55.44, 50.40, 49.11, 48.76, 48.54, 44.27, 42.64, 40.75, 38.85, $38.24,37.52,37.18,34.49,32.24,29.78,29.72,27.87,27.04,26.97$, $22.88,22.76,20.99,18.35,16.03,15.90,15.34,14.59$. HRMS, calcd. $\left(\mathrm{M}+\mathrm{H}^{+}\right) \mathrm{m} / \mathrm{e} 459.3838$, observed 459.3510 . 


\section{3( $\alpha)$-Hydroxylupan-28-oic acid $(9 \alpha)$}

Prepared as previously described for $\mathbf{3 \alpha}$ and $\mathbf{9 \beta}$. Yield: $49.9 \%$ (five steps). ${ }^{1} \mathrm{H} \mathrm{NMR}\left(300 \mathrm{MHz}, \mathrm{CDCl}_{3}\right) \delta 3.39$ (s, $\left.1 \mathrm{H}\right), 2.28$ $2.16(\mathrm{~m}, 2 \mathrm{H}), 1.98-1.78(\mathrm{~m}, 4 \mathrm{H}), 1.64-0.96(\mathrm{~m}$, other aliphatic ring protons), $0.96(\mathrm{~s}, 3 \mathrm{H}), 0.93(\mathrm{~s}, 3 \mathrm{H}), 0.92(\mathrm{~s}, 3 \mathrm{H}), 0.90$ (s, $3 \mathrm{H}), 0.89$ (s, 3H), 0.87 (s, 3H), 0.78 (s, 3H). ${ }^{13} \mathrm{C} \mathrm{NMR}(75 \mathrm{MHz}$, $\left.\mathrm{CDCl}_{3}+\mathrm{CD}_{3} \mathrm{OD}\right) \delta 179.68,76.17,56.86,50.21,49.10,48.87$, $44.38,42.81,41.03,38.31,37.64,37.58,37.38,34.45,33.43,32.34$, $29.89,29.78,28.28,27.16,25.40,23.00,22.88,22.23,20.95,18.38$, $15.99(2 * \mathrm{C}), 14.70,14.66$. HRMS, calcd. $\left(\mathrm{M}+\mathrm{H}^{+}\right) \mathrm{m} / \mathrm{e} 459.3838$, observed 459.3513 .

\section{3( $\alpha$ )-Acetoxylupan-28-oic acid (11 $\alpha)$}

Prepared as previously described for 8a and 9a. Yield: $32.4 \%$ (six steps). ${ }^{1} \mathrm{H}$ NMR (300 MHz, $\mathrm{CDCl}_{3}$ ) $\delta 4.62$ (s, 1H), 2.84-2.20 $(\mathrm{m}, 4 \mathrm{H}), 2.08(\mathrm{~s}, 3 \mathrm{H}), 1.98-1.15$ (m, other aliphatic ring protons), $1.01(\mathrm{~s}, 3 \mathrm{H}), 0.94(\mathrm{~s}, 3 \mathrm{H}), 0.92(\mathrm{~s}, 3 \mathrm{H}), 0.85(\mathrm{~s}, 3 \mathrm{H}), 0.83(\mathrm{~s}, 3 \mathrm{H})$, $0.76(\mathrm{~s}, 3 \mathrm{H}), 0.74(\mathrm{~s}, 3 \mathrm{H}) .{ }^{13} \mathrm{C}$ NMR $\left(75 \mathrm{MHz}, \mathrm{CDCl}_{3}\right) \delta$ 182.57, 171.05, 78.60, 57.08, 50.44, 50.27, 49.00, 44.41, 42.90, 41.11, 38.48, $37.64,37.41,36.89,34.40,34.12,32.32,29.94(2 * \mathrm{C}), 28.02,27.10$, 23.19, 23.10, 22.97, 21.92, 21.59, 20.93, 18.32, 16.30, 16.07, 15.06, 14.87. HRMS, calcd. $\left(\mathrm{M}+\mathrm{H}^{+}\right) \mathrm{m} / \mathrm{e} 501.3944$, observed 501.3761.

\section{3(ß)-Acetoxylupan-28-oic acid (11ß)}

Prepared as previously described for $\mathbf{8} \boldsymbol{\beta}$ and $\mathbf{9 \beta}$. Yield: $34.6 \%$ (four steps). ${ }^{1} \mathrm{H}$ NMR (300 MHz, $\left.\mathrm{CDCl}_{3}\right) \delta 4.47(\mathrm{t}, 1 \mathrm{H}, \mathrm{J}=9.0$ $\mathrm{Hz}), 2.28-2.14(\mathrm{~m}, 4 \mathrm{H}), 2.03(\mathrm{~s}, 3 \mathrm{H}), 1.89-1.12$ (m, other aliphatic ring protons), $0.94(\mathrm{~s}, 3 \mathrm{H}), 0.91(\mathrm{~s}, 3 \mathrm{H}), 0.85(\mathrm{~s}, 3 \mathrm{H}), 0.83$ $(\mathrm{s}, 3 \mathrm{H}), 0.82(\mathrm{~s}, 3 \mathrm{H}), 0.76(\mathrm{~s}, 3 \mathrm{H}), 0.73(\mathrm{~s}, 3 \mathrm{H}) .{ }^{13} \mathrm{C}$ NMR $(75$ $\left.\mathrm{MHz} \mathrm{CDCl}_{3}\right) \delta 183.24,171.30,81.20,57.08,55.59,50.37,48.98$, $44.41,42.76,40.91,38.59,38.49,38.01,37.63,37.31,34.52,32.29$, $29.93(2 * \mathrm{C}), 28.17,27.05,23.90,23.20,22.97,21.51,21.10,18.38$, $16.68,16.34,16.31,14.89,14.79$. HRMS, calcd. $\left(\mathrm{M}+\mathrm{H}^{+}\right) \mathrm{m} / \mathrm{e}$ 501.3944 , observed 501.3754 .

\section{3( $\alpha$ )-Propionyloxylupan-28-oic acid (12 $\alpha)$}

Prepared as previously described for 11a and 9a. Yield: $22.5 \%$ (six steps). ${ }^{1} \mathrm{H}$ NMR (300 MHz, $\left.\mathrm{CDCl}_{3}\right) \delta 4.62$ (s, 1H), 2.36 (q, $2 \mathrm{H}), 2.28-2.15(\mathrm{~m}, 4 \mathrm{H}), 1.91-1.83(\mathrm{~m}, 4 \mathrm{H}), 1.69-1.10(\mathrm{~m}$, other aliphatic ring protons), $1.16(\mathrm{t}, 3 \mathrm{H}, \mathrm{J}=6.0 \mathrm{~Hz}), 1.00(\mathrm{~s}, 3 \mathrm{H}), 0.94$ $(\mathrm{s}, 3 \mathrm{H}), 0.87(\mathrm{~s}, 3 \mathrm{H}), 0.85(\mathrm{~s}, 3 \mathrm{H}), 0.83(\mathrm{~s}, 3 \mathrm{H}), 0.77(\mathrm{~s}, 3 \mathrm{H}), 0.74$ $(\mathrm{s}, 3 \mathrm{H}) .{ }^{13} \mathrm{C} \mathrm{NMR}\left(75 \mathrm{MHz}, \mathrm{CDCl}_{3}\right) \delta 182.67,174.27,78.31$, 57.08, 50.53, 50.31, 49.00, 44.41, 42.86, 41.10, 38.48, 37.64, 37.40, $36.97,34.43,34.16,32.32,29.94,28.70,28.35,28.08,27.10,23.20$, 23.11, 22.97, 21.91, 20.92, 18.32, 16.30, 16.08, 15.01, 14.88, 9.66. HRMS, calcd. $\left(\mathrm{M}+\mathrm{Na}^{+}\right) \mathrm{m} / \mathrm{e}$ 537.3920, observed 537.3904.

\section{3( $\beta$ )-Propionyloxylupan-28-oic acid (12 $\beta$ )}

Prepared as previously described for $\mathbf{1 1} \boldsymbol{\beta}$ and $\mathbf{9} \boldsymbol{\beta}$. Yield: $69.5 \%$ (four steps). ${ }^{1} \mathrm{H}$ NMR (300 MHz, $\left.\mathrm{CDCl}_{3}\right) \delta 4.47$ (t, 1H, J=7.5 $\mathrm{Hz}), 2.32$ (q, 2H), 2.30-2.14 (m, 4H), 1.90-1.77 (m, 4H), 1.69$1.10(\mathrm{~m}$, other aliphatic ring protons $), 1.13(\mathrm{t}, 3 \mathrm{H}, \mathrm{J}=6.0 \mathrm{~Hz})$, $0.94(\mathrm{~s}, 3 \mathrm{H}), 0.91(\mathrm{~s}, 3 \mathrm{H}), 0.85(\mathrm{~s}, 3 \mathrm{H}), 0.83(\mathrm{~s}, 3 \mathrm{H}), 0.78(\mathrm{~s}, 3 \mathrm{H})$, $0.76(\mathrm{~s}, 3 \mathrm{H}), 0.74(\mathrm{~s}, 3 \mathrm{H}) .{ }^{13} \mathrm{C} \mathrm{NMR}\left(75 \mathrm{MHz}, \mathrm{CDCl}_{3}\right) \delta 183.36$, 174.60, 80.87, 57.08, 55.58, 50.35, 48.97, 44.40, 42.76, 40.90, 38.56, $38.49,38.10,37.63,37.31,34.50,32.28,29.94(2 * \mathrm{C}), 28.31,28.18$,
27.06, 23.93, 23.22, 22.97, 21.09, 18.37, 16.74, 16.35, 16.31, 14.90, 14.81, 9.58. HRMS, calcd. $\left(\mathrm{M}+\mathrm{Na}^{+}\right) \mathrm{m} / \mathrm{e}$ 537.3920, observed 537.3926 .

\section{3( $\alpha$ )-Butyryloxylupan-28-oic acid $(13 \alpha)$}

Prepared as previously described for 11a and 9a. Yield: $47.9 \%$ (six steps). ${ }^{1} \mathrm{H}$ NMR (300 MHz, $\left.\mathrm{CDCl}_{3}\right) \delta 4.61$ (s, 1H), 2.30 (t, $2 \mathrm{H}, \mathrm{J}=7.5 \mathrm{~Hz}), 2.28-2.15(\mathrm{~m}, 4 \mathrm{H}), 1.98-1.15$ (m, other aliphatic ring protons), $0.94(\mathrm{~s}, 3 \mathrm{H}), 0.91(\mathrm{~s}, 3 \mathrm{H}), 0.90(\mathrm{t}, 3 \mathrm{H}, \mathrm{J}=6.0 \mathrm{~Hz})$, 0.85 (s, 3H) $0.83(\mathrm{~s}, 3 \mathrm{H}), 0.82(\mathrm{~s}, 3 \mathrm{H}), 0.75(\mathrm{~s}, 3 \mathrm{H}), 0.73$ (s, $3 \mathrm{H}) .{ }^{13} \mathrm{C} \mathrm{NMR}\left(75 \mathrm{MHz}, \mathrm{CDCl}_{3}\right) \delta 183.02,173.83,80.86,57.06$, 50.39 , 48.92, 47.30, 44.35, 42.76, 40.92, 38.57, 38.03, 37.61, 36.96, $32.29,31.66,29.91,29.71,28.14,27.07,25.37,23.92,22.82,21.09$, $19.09,18.83,18.38,17.63,16.74,16.30,14.10,13.98,12.35,11.93$. HRMS, calcd. $\left(\mathrm{M}+\mathrm{Na}^{+}\right)$m/e 551.4076, observed 551.3588.

\section{3( $\beta$ )-Butyryloxylupan-28-oic acid (13ß)}

Prepared as previously described for $\mathbf{1 1} \boldsymbol{\beta}$ and $\mathbf{9} \boldsymbol{\beta}$. Yield: $74.5 \%$ (four steps). ${ }^{1} \mathrm{H}$ NMR (300 MHz, $\left.\mathrm{CDCl}_{3}\right) \delta 4.48(\mathrm{t}, 1 \mathrm{H}, \mathrm{J}=7.5$ $\mathrm{Hz}), 2.28(\mathrm{t}, 2 \mathrm{H}, \mathrm{J}=7.5 \mathrm{~Hz}), 2.30-2.15(\mathrm{~m}, 4 \mathrm{H}), 1.90-1.07$ (m, other aliphatic ring protons), $0.94(\mathrm{~s}, 3 \mathrm{H}), 0.91(\mathrm{~s}, 3 \mathrm{H}), 0.90(\mathrm{t}$, $3 \mathrm{H}, \mathrm{J}=6.0 \mathrm{~Hz}), 0.85(\mathrm{~s}, 3 \mathrm{H}), 0.83(\mathrm{~s}, 3 \mathrm{H}), 0.82(\mathrm{~s}, 3 \mathrm{H}), 0.75$ (s, $3 \mathrm{H}), 0.73(\mathrm{~s}, 3 \mathrm{H}) .{ }^{13} \mathrm{C} \mathrm{NMR}\left(75 \mathrm{MHz}, \mathrm{CDCl}_{3}\right) \delta 183.12,173.85$, $80.88,57.08,55.61,50.41,48.93,47.31,44.36,42.78,40.94,38.59$, $38.43,38.05,37.63,37.30,36.99,34.53,32.24,31.66,29.72,28.16$, $27.09,25.38,23.94,23.18,22.83,21.11,18.85,18.39,16.76,16.32$, 14.11, 11.95. HRMS, calcd. $\left(\mathrm{M}+\mathrm{Na}^{+}\right) \mathrm{m} / \mathrm{e} 551.4076$, observed 551.3555 .

\section{3( $\alpha)$-Cyclopropyl formyloxylupan-28-oic acid $(14 \alpha)$}

Prepared as previously described for 11a and 9a. Yield: $26.5 \%$ (six steps). ${ }^{1} \mathrm{H} \mathrm{NMR}$ (300 MHz, $\mathrm{CDCl}_{3}$ ) $\delta 4.61$ (s, 1H), 2.28-2.15 $(\mathrm{m}, 1 \mathrm{H}+2 \mathrm{H}), 1.91-1.83(\mathrm{~m}, 4 \mathrm{H}), 1.69-1.15(\mathrm{~m}$, other aliphatic ring protons), $1.00(\mathrm{~s}, 3 \mathrm{H}), 0.94(\mathrm{~s}, 3 \mathrm{H}), 0.87(\mathrm{~s}, 3 \mathrm{H}), 0.85$ (s, $3 \mathrm{H}), 0.83$ (s, 3H), $0.77(\mathrm{~s}, 3 \mathrm{H}), 0.74(\mathrm{~s}, 3 \mathrm{H}) .{ }^{13} \mathrm{C} \mathrm{NMR}(75 \mathrm{MHz}$, $\left.\mathrm{CDCl}_{3}\right) \delta 182.95,174.56,78.35,57.10,50.61,50.35,49.00,44.41$, $42.85,41.10,38.48,37.65,37.39,37.05,34.46,34.22,32.33,29.94$ $(2 * \mathrm{C}), 28.08,27.10,23.20,23.07,22.97,21.91,20.93,18.31,16.31$, $16.09,15.01,14.88,13.57,8.43,8.29$. HRMS, calcd. $\left(\mathrm{M}+\mathrm{Na}^{+}\right) \mathrm{m} /$ e 549.3920, observed 549.3902 .

\section{3(ß)-Cyclopropyl formyloxylupan-28-oic acid (14ß)}

Prepared as previously described for $\mathbf{1 1} \boldsymbol{\beta}$ and $\mathbf{9} \boldsymbol{\beta}$. Yield: 49.2\% (four steps). $\left.{ }^{1} \mathrm{H} \mathrm{NMR} \mathrm{(300} \mathrm{MHz,} \mathrm{CDCl}_{3}\right) \delta 4.46(\mathrm{t}, 1 \mathrm{H}$, $\mathrm{J}=7.5 \mathrm{~Hz}), 2.28-2.15(\mathrm{~m}, 1 \mathrm{H}+2 \mathrm{H}), 1.90-1.79(\mathrm{~m}, 4 \mathrm{H}), 1.69-1.15$ ( $\mathrm{m}$, other aliphatic ring protons), $0.95(\mathrm{~s}, 3 \mathrm{H}), 0.92(\mathrm{~s}, 3 \mathrm{H})$, 0.85 (s, 3H), 0.83 (s, 3H), 0.78 (s, 3H), 0.76 (s, 3H), $0.74(\mathrm{~s}, 3 \mathrm{H})$. ${ }^{13} \mathrm{C}$ NMR $\left(75 \mathrm{MHz} \mathrm{CDCl}_{3}\right) \delta 182.64,174.85,80.91,57.06,55.61$, 50.36, 48.97, 44.40, 42.78, 40.91, 38.57, 38.48, 38.16, 37.62, 37.31, $34.52,32.28,29.93(2 * \mathrm{C}), 28.17,27.06,23.91,23.21,22.96,21.09$, 18.37, 16.75, 16.34, 16.30, 14.90, 14.81, 13.53, 8.38, 8.34. HRMS, calcd. $\left(\mathrm{M}+\mathrm{Na}^{+}\right) \mathrm{m} / \mathrm{e} 549.3920$, observed 549.4020 .

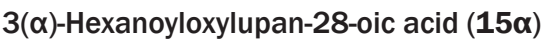

Prepared as previously described for 11a and 9a. Yield: 78.3\% (six steps). ${ }^{1} \mathrm{H}$ NMR (300 MHz, $\left.\mathrm{CDCl}_{3}\right) \delta 4.60$ (s, 1H), 2.30 (t, 
2H, J=7.5 Hz), 2.28-2.15 (m, 4H), 1.98-1.15 (m, other aliphatic ring protons), $0.94(\mathrm{~s}, 3 \mathrm{H}), 0.91(\mathrm{~s}, 3 \mathrm{H}), 0.90(\mathrm{t}, 3 \mathrm{H}, \mathrm{J}=6.0 \mathrm{~Hz})$, 0.85 (s, 3H), 0.83 (s, 3H), 0.82 (s, 3H), 0.75 (s, 3H), 0.73 (s, 3H). ${ }^{13} \mathrm{C}$ NMR $\left(75 \mathrm{MHz}, \mathrm{CDCl}_{3}\right) \delta 183.69,173.71,80.89,57.08,50.52$, $48.94,45.83,44.36,42.80,42.73,41.07,40.89$, 38.41, 38.01, 37.35, $36.89,34.98,32.45,32.14,31.91,31.56,29.93,29.76,29.47,28.12$, 27.55, 27.08, 25.05, 22.85, 21.87, 20.90, 18.30, 16.16, 14.85, 14.27, 14.13. HRMS, calcd. $\left(\mathrm{M}+\mathrm{K}^{+}\right) \mathrm{m} / \mathrm{e} 595.4132$, observed 595.3814 .

\section{3( $\beta$ )-Hexanoyloxylupan-28-oic acid (15 $\beta$ )}

Prepared as previously described for $\mathbf{1 1} \boldsymbol{\beta}$ and $\mathbf{9} \boldsymbol{\beta}$. Yield: $56.5 \%$ (four steps). ${ }^{1} \mathrm{H} \mathrm{NMR}\left(300 \mathrm{MHz}, \mathrm{CDCl}_{3}\right) \delta 4.48(\mathrm{t}, 1 \mathrm{H}, \mathrm{J}=7.5$ $\mathrm{Hz}), 2.28(\mathrm{t}, 2 \mathrm{H}, \mathrm{J}=7.5 \mathrm{~Hz}), 2.30-2.15(\mathrm{~m}, 4 \mathrm{H}), 1.90-1.07$ (m, other aliphatic ring protons), $0.94(\mathrm{~s}, 3 \mathrm{H}), 0.91(\mathrm{~s}, 3 \mathrm{H}), 0.90(\mathrm{t}$, $3 \mathrm{H}, \mathrm{J}=6.0 \mathrm{~Hz}), 0.85(\mathrm{~s}, 3 \mathrm{H}), 0.83(\mathrm{~s}, 3 \mathrm{H}), 0.82(\mathrm{~s}, 3 \mathrm{H}), 0.75$ (s, $3 \mathrm{H}), 0.73(\mathrm{~s}, 3 \mathrm{H}) .{ }^{13} \mathrm{C} \mathrm{NMR}\left(75 \mathrm{MHz}, \mathrm{CDCl}_{3}\right) \delta 182.71,177.86$, 80.82, 57.06, 55.61, 50.37, 48.98, 44.41, 42.78, 40.92, 38.58, 38.49, $38.06,37.63,37.32,35.03,34.53,32.28,31.81,31.56,29.93,28.18$, $25.05,23.94,22.95,22.87,22.53,21.10,18.38,16.99,16.75,16.33$, 14.88, 14.32, 14.12, 11.64. HRMS, calcd. $\left(\mathrm{M}+\mathrm{Na}^{+}\right) \mathrm{m} / \mathrm{e}$ 579.4384, observed 579.3664 .

\section{Acknowledgements}

This work was supported by grants from the National Science and Technology Major Projects for Major New Drugs Innovation and Development (No 2012ZX09304011, 2013ZX09507001, and 2012ZX09301001-005), National Basic Research Program of China (973 Program) (№ 2014CB541906) and the National Natural Science Foundation of China (№ 30725049 and 81202341).

\section{Author contribution}

Fa-jun NAN and Xin XIE designed the research; Xiao-yin WANG, Shu-yong ZHANG, Jing LI, and Hua-nan LIU performed the research; all authors analyzed the data; Xiao-yin WANG wrote the paper.

\section{References}

1 Maruyama T, Miyamoto Y, Nakamura T, Tamai Y, Okada H, Sugiyama E, et al. Identification of membrane-type receptor for bile acids (M-BAR). Biochem Biophys Res Commun 2002; 298: 714-9.

2 Kawamata Y, Fujii R, Hosoya M, Harada M, Yoshida H, Miwa M, et al. A G protein-coupled receptor responsive to bile acids. J Biol Chem 2003; 278: 9435-40.

3 Zhang JL, Wang $\mathrm{H}$, Chen $\mathrm{C}$, Pi HF, Raun $\mathrm{HL}$, Zhang P, et al. Addictive evaluation of cholic acid-verticinone ester, a potential cough therapeutic agent with agonist action of opioid receptor. Acta Pharmacol Sin 2009; 30: 559-66.

4 Makishima M, Okamoto AY, Repa JJ, Tu H, Learned RM, Luk A, et al. Identification of a nuclear receptor for bile acids. Science 1999; 284: 1362-5.

5 Parks DJ, Blanchard SG, Bledsoe RK, Chandra G, Consler TG, Kliewer $\mathrm{SA}$, et al. Bile acids: natural ligands for an orphan nuclear receptor. Science 1999; 284: 1365-8.

6 Pols TW, Noriega LG, Nomura M, Auwerx J, Schoonjans K. The bile acid membrane receptor TGR5 as an emerging target in metabolism and inflammation. J Hepatol 2011; 54: 1263-72.

7 Thomas C, Gioiello A, Noriega L, Strehle A, Oury J, Rizzo G, et al.
TGR5-mediated bile acid sensing controls glucose homeostasis. Cell Metab 2009; 10: 167-77.

8 Pols TW, Nomura M, Harach T, Lo Sasso G, Oosterveer MH, Thomas $\mathrm{C}$, et al. TGR5 activation inhibits atherosclerosis by reducing macrophage inflammation and lipid loading. Cell Metab 2011; 14: 747-57.

9 Parker HE, Wallis K, le Roux CW, Wong KY, Reimann F, Gribble FM. Molecular mechanisms underlying bile acid-stimulated glucagon-like peptide-1 secretion. Br J Pharmacol 2012; 165: 414-23.

10 Watanabe M, Houten SM, Mataki C, Christoffolete MA, Kim BW, Sato H, et al. Bile acids induce energy expenditure by promoting intracellular thyroid hormone activation. Nature 2006; 439: 484-9.

11 Pellicciari R. TGR5 modulators and method of use thereof. WO patent 059853A1. 2011 Oct 27.

12 Roche HL. 4-phenoxy-nicotinamide or 4-phenoxy-pyrimidine-5carboxamide compounds. WO patent 089099A1. 2011 July 28.

13 Raval S. Compounds and compositions as TGR5 agonists: W02012082947. Expert Opin Ther Pat 2013; 23: 531-6.

14 Keitel V, Cupisti K, Ullmer C, Knoefel WT, Kubitz R, Haussinger D. The membrane-bound bile acid receptor TGR5 is localized in the epithelium of human gallbladders. Hepatology 2009; 50: 861-70.

15 Pellicciari R, Gioiello A, Macchiarulo A, Thomas C, Rosatelli E, Natalini $\mathrm{B}$, et al. Discovery of 6 alpha-ethyl-23(S)-methylcholic acid (S-EMCA, INT-777) as a potent and selective agonist for the TGR5 receptor, a novel target for diabesity. J Med Chem 2009; 52: 7958-61.

16 Pellicciari R. TGR5 modulators and methods for use thereof. US paptet 0115832A1. 2012 May 10.

17 Takikawa HH, Hirooka M, Sasaki M. The first synthesis of ( \pm )-brevione $\mathrm{B}$, an allelopathic agent isolated from Penicillium sp. Tetrahedron Lett 2003; 44: 5235-8.

18 Blazevski J, Petkovic F, Momcilovic M, Paschke R, Kaluderovic GN, Mostarica Stojkovic M, et al. Betulinic acid regulates generation of neuroinflammatory mediators responsible for tissue destruction in multiple sclerosis in vitro. Acta Pharmacol Sin 2013; 34: 424-31.

19 Genet C, Strehle A, Schmidt C, Boudjelal G, Lobstein A, Schoonjans $\mathrm{K}$, et al. Structure-activity relationship study of betulinic acid, a novel and selective TGR5 agonist, and its synthetic derivatives: potential impact in diabetes. J Med Chem 2010; 53: 178-90.

20 Genet C, Schmidt C, Strehle A, Schoonjans K, Auwerx J, Saladin R, et al. Redefining the TGR5 triterpenoid binding pocket at the C-3 position. ChemMedChem 2010; 5: 1983-8.

21 Dess DB, Martin JC. A useful 12-I-5 triacetoxyperiodinane (the Dess-Martin periodinane) for the selective oxidation of primary or secondary alcohols and a variety of related 12-I-5 species. J Am Chem Soc 1991; 113: 7277-87.

22 Corey EJ, Bakshi RK. Highly enantioselective borane reduction of ketones catalyzed by chiral oxazaborolidines. Mechanism and synthetic implication. J Am Chem Soc 1987; 109: 5551-3.

23 Imahori T, Ojima H, Yoshimura $\mathrm{Y}$, Takahata H. Acceleration effect of an allylic hydroxy group on ring-closing enyne metathesis of terminal alkynes: scope, application, and mechanistic insights. Chemistry 2008; 14: 10762-71.

24 Evans KA, Budzik BW, Ross SA, Wisnoski DD, Jin J, Rivero RA, et al. Discovery of 3-aryl-4-isoxazolecarboxamides as TGR5 receptor agonists. J Med Chem 2009; 52: 7962-5.

25 Duan H, Ning M, Chen X, Zou Q, Zhang L, Feng Y, et al. Design, synthesis, and antidiabetic activity of 4-phenoxynicotinamide and 4-phenoxypyrimidine-5-carboxamide derivatives as potent and orally efficacious TGR5 agonists. J Med Chem 2012; 55: 10475-89.

26 Londregan AT, Piotrowski DW, Futatsugi K, Warmus JS, Boehm M, Carpino $\mathrm{P}$, et al. Discovery of 5-phenoxy-1,3-dimethyl-1H-pyrazole-4carboxamides as potent agonists of TGR5 via sequential combinatorial 
libraries. Bioorg Med Chem Lett 2013; 23: 1407-11.

27 Piotrowski DW, Warmus FK, Orr JS, Freeman-Cook STM, Londregan $\mathrm{KD}$, Wei AT, et al. Identification of tetrahydropyrido[4.3-d]pyrimidine amides as a new class of orally bioavailable TGR5 agonists. ACS Med Chem Lett 2012; 4: 43-68.

28 Rajendran P, Jaggi M, Singh MK, Mukherjee R, Burman AC. Pharmacological evaluation of C-3 modified betulinic acid derivatives with potent anticancer activity. Invest New Drugs 2008; 26: 25-34.

29 Jager S, Winkler K, Pfuller U, Scheffler A. Solubility studies of oleanolic acid and betulinic acid in aqueous solutions and plant extracts of Viscum album L. Planta Med 2007; 73: 157-62.

30 Vieth M, Sutherland JJ. Dependence of molecular properties on proteomic family for marketed oral drugs. J Med Chem 2006; 49: 3451-3. 